Journal of Al Azhar University Engineering Sector

Vol. 14, No. 52, July 2019, 1089-1107

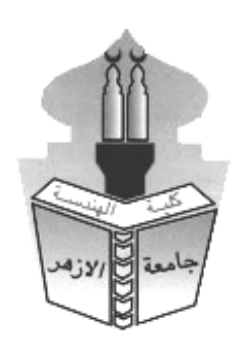

\title{
ASSESSMENT OF PARTICIPATORY URBAN DEVELOPMENT APPROACHES IN EGYPT "TOWARDS MORE JUST CITIES"
}

\author{
Omneya Mohamed Eid, Adel Samy El Menshawy and Ahmed Moussa Salman \\ Arab Academy For Science and Technology and Maritime Transport, Architectural \\ Engineering and Environmental Design Department \\ Omneya.m.eid@hotmail.comm dradelsamy@yahoo.com, Ahmed.mousa@hotmail.com
}

\begin{abstract}
The 'spatialization' of justice and the desire for more 'Just Cities' has been increasingly receiving the attention of many urban theorists. Recent theories of urban planning emphasizes on democratic urban planning processes as a key to justice, in other words, the elimination of domination and oppression in urban planning. Yet, as a concept, justice is often taken for granted as an end result in the urban development plans. As our right to the city is shaped by our spatial experience, the purpose of this paper is to assess the participatory urban development projects' processes and their outcomes in terms of spatial justice, taking place in Egypt. The paper investigates the extent to which expanding the role of ordinary citizens in the development process can yield socially and spatially just outcomes. Ezzbet El Nasr in Cairo is chosen for the case study. It is examined through a set of criteria to help evaluate the participatory development projects that took place by the GIZ-PDP in the area. The paper will conclude with a set of recommendations on how the city resident can contribute, connect and prosper to reach their full potential through their spatial experience.
\end{abstract}

Keywords : Right to the city, spatial justice, participatory urban development, GIZ-PDP in Egypt0

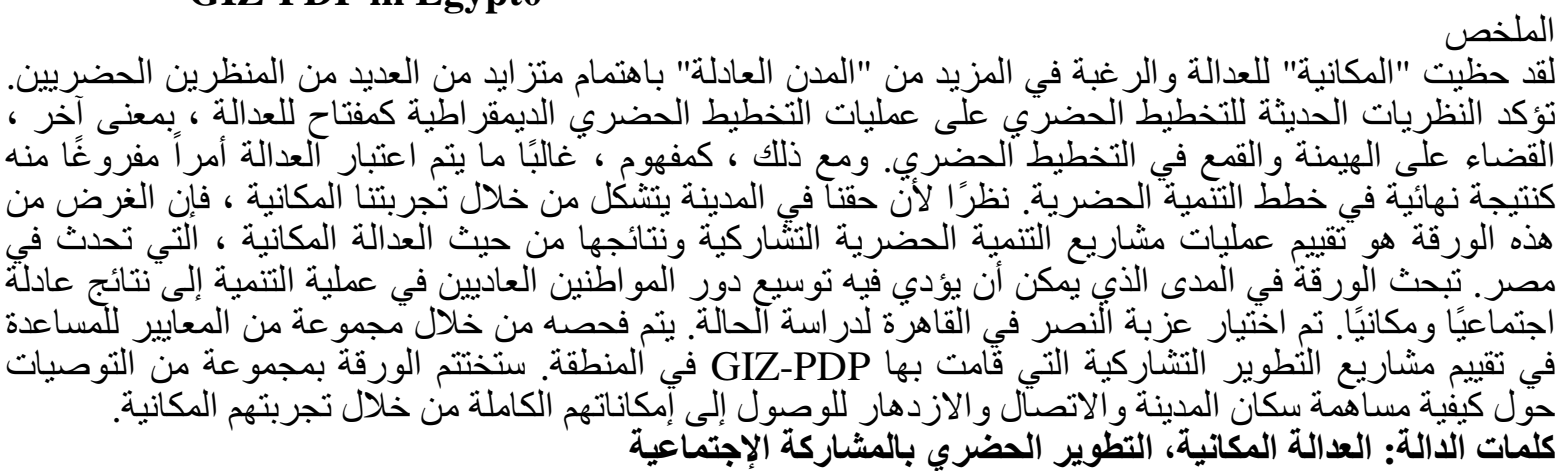

\section{INTRODUCTION}

Originating in the nineteenth century, the vision of city planning was to defeat the outcomes of the industrial revolution, and make good liveable and more just cities. But today's cities are full of injustices and unrealized promises of opportunities and liberation. In order to make cities good again urban redevelopment policies are discussed and projects are carried out to try to make balance in a context full of concentrations of inequality, insecurity and exploitation. Meanwhile, more urban thinkers focused on the inadequacies of planning processes and methodology, arguing that comprehensive planning was inherently undemocratic, unattainable and unjust. (Raveshty \& Hoseyni, 2010)

Seeking to promote justice or in other words decrease injustice acts is a fundamental objective in all societies for sustaining human dignity and fairness. A foundational principal related to 
other notions of democracy, equality, citizenship and civil rights. Justice is considered a contemporary demand facing the injustices of the growing economic inequalities and social segregation (Soja, 2009). Such inequalities ignited the people in the Arab spring of 2011, as the people took over city squares and plazas, expressing their outrage and calling for 'social justice' hand in hand with 'Bread and freedom' (fig 1), a revolution that led to the over-throw of the long-standing rulers of Egypt, Libya and Tunisia. Later the demand for social justice was manifested in spatial justice and the need for tackling urban inequalities.

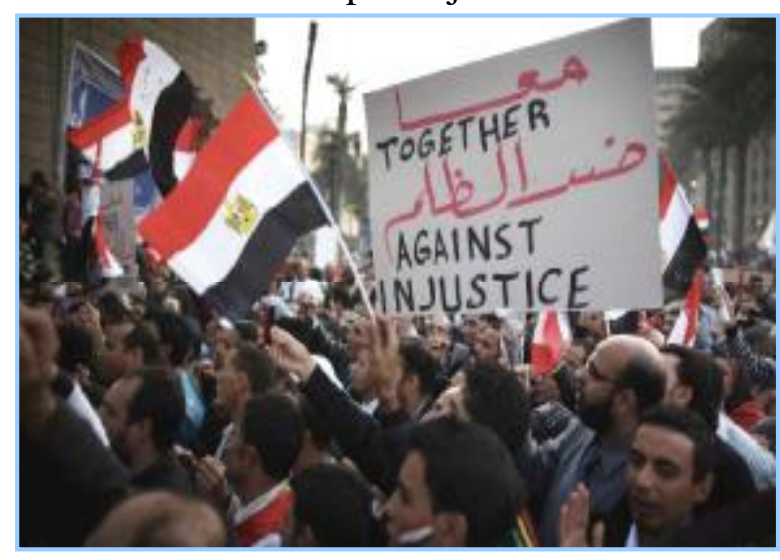

Figure 1, the Egyptian revolution of 2011

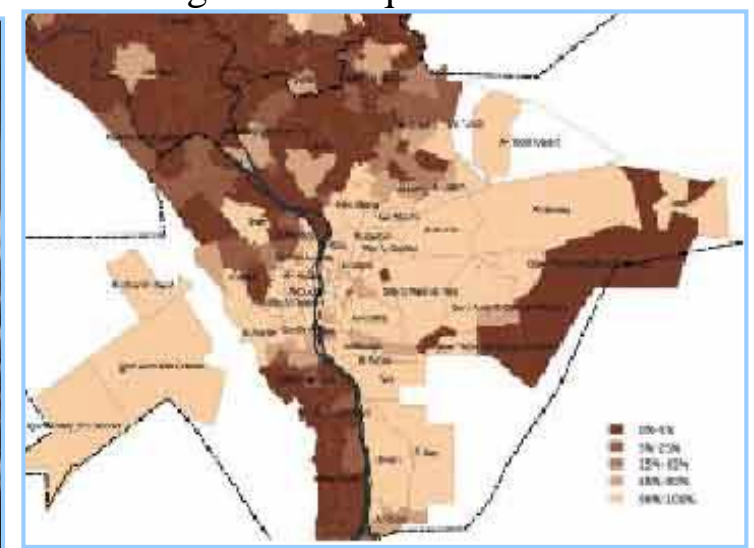

Figure 2, Cairo unjust geographies of sewage connection

\section{RESEARCH QUESTIONS}

1-Does participating in democratic decision making processes yield more spatially just urban environments?

2-How can spatial justice be conceived in the context of governmental urban upgrading initiatives, especially in poor urban areas?

\section{RESEARCH OBJECTIVES}

1-Examine the Egyptian context and review the unjust acts in urban development as to develop a broader understanding of the related issues.

2-It seeks to find an analytical framework in the theoretical discourse of the right to the city, which would help to understand the democratic participatory development processes that can formulate more spatially 'just' urban environments and enable a critical evaluation of the findings.

3-It seeks further investigation of the approaches to spatial justice through the analysis of global examples

4-It's aim is to assess the potential of the GIZ-PDP participatory development program in upgrading Egypt's urban environment.

5-Based on the diagnosis of the program, it will set recommendations to strengthen the program's potential in order to reach the envisioned goal of spatial justice.

\section{RESEARCH METHODOLOGY}

The exploratory nature of the research requires adopting a qualitative approach as the most logical option to reveal the different factors affecting spatial justice. The study is classified into three parts:

- Inductive and deductive: Through literature review that studies the theories of urban justice in the city and deepen the understanding of the characteristics of participatory planning as an approach to more spatial justice, to develop an analytical framework to assess such approaches

- Analytical study: Through analyzing relevant examples that succeeded in approaching more spatial justice for the community people through their inclusion in decision- 
making processes, to further develop the assessment framework

- Field of work: Through field survey and interviews in a chosen case study, where the achieved criteria are applied.

\section{Key issues of urban development in Egypt}

The search for more just urban planning begins with the examination of injustice acts of the rapid urbanization, the physical expressions of unequal access to social, cultural, political, and economic capital that arise from the divisions between race, class, and gender categories.

\subsection{Centralization and unjust spatial distribution of resources and services}

In a centralized state, the government is responsible for deciding on the distribution of public resources and services among the different neighborhoods of the state, without any participation from the public in decision-making to assess their needs (fig 2). Resulting in uneven urban development and misallocation of resources and services that doesn't respond to local needs. In addition to the lack of proper indicators of these forms of unjust distribution, many pockets of deprivation remain invisible, which make it extremely difficult for officials to target such forms of deprivation. (Tadamun, 2015)

\subsection{Spatial inequality in expenditure on urban development}

From the analysis of the national budget expenditure of the financial year 2015/2016, a total of 98.9 billion Egyptian pounds were spent on the built environment. Where $40 \%$ of the budget spent on regional projects; power stations, railroads and regional highways, while $31 \%$ of the budget is spent on new cities benefiting only $2 \%$ of the population. The rest of the budget was spent on existing cities where $98 \%$ of the Egyptians live, benefiting from only $29 \%$ of the built environment budget. All regions suffered from internal spending disparities, with one or two governorates receiving above or high above average spending in a number of sectors, while others receiving below or well below average per capita spending in most if not all sectors. This large range of per capita spending indicates that spending is not necessarily needs based. (Shawkat and Khalil, 2016)0

\subsection{Lack of transparency}

The right to information and access to public information concerning budgets, infrastructure projects and allocation of resources, is considered one of the main pillars of democracy. In urban development projects lack of information can result in access to outdated information or the duplications of data collection. Therefore, governmental activities will be inefficient. Access to information in urban projects is crucial for the citizens to engage effectively. Problems and constraints must be known publicly. Information empowers the people especially the marginalized communities and gain them recognition by the public authorities. In many areas, urban development projects are carried out without the affected community knowing what the project is about, or how it will affect their quality of life, or how their neighborhood will benefit from it. The projects are carried out without even having representatives of this community to vote for or against these types of projects. Transparency allow the people to act against these unjust projects and misallocation of resources. (Tadamun, 2013)

\subsection{Power imbalances}

Although in theory, traditional urban development is dominated by professional groups of urbanists, engineers, and architects, yet other social groups and organization can participate and affect the process outcome. In societies dominated by capitalist economic systems like Egypt, the social elite form the most influential social group, in particular entrepreneurs and business organizations operating in the property markets. This leads to the marginalization 
of other social groups representing the civil society who finds it difficult to actively participate in urban processes, which result in further unfulfilled wants and needs. (Martinez, 2010)

Therefore, a need for the notion of a just civil participation is crucial. The notion could be defined as a set of practices in urban planning by which the 'civil society - the population that doesn't belong to the social elite or govern - can use its capacities to intermediate in collective life. Capacities like decision-making and influencing the rulers' decisions, the ability to perform in the distribution of resources, the ability to access institutions where matters of the public interests are negotiated and the capability of exercising democracy and power-sharing. (Martinez, 2010)0

\section{SPATIAL JUSTICE IN URBAN DEVELOPMENT}

Spatial justice brings together social justice and space, and how space is organized is a crucial dimension in society. Therefore to tackle social justice, a closer look at space and the people using it is needed. In the past years, there has been an increasing interest in the concept of spatial justice, and how it can suggest new ideas in solving urban inequalities.

From the work of many justice philosophers and urban geographers, there seems to be two complementing theories of spatial justice. (Schwab, 2018)

One of them centers socio-spatial redistribution issues or the set of approaches, which aim at increasing equality in the distribution of the peoples' wants and needs. This can include access to adequate housing, education, health care facilities, as well as good quality urban environment. Such urban inequalities in this area can be clearly seen in a trend of increasingly limited access to many spaces like the privatization or semi-privatization of urban public spaces. In this school of distributive urban justice, it is the access of these goods or social opportunities that sets the indicator that whether the space is just or unjust. (Schwab, 2018) The second school puts participation in shaping one's life in the center of it. It focuses on decision-making processes. This approach focuses on approaches that help understand spatial representation, identities and social practices, and how they are experienced and managed in space. Processes that values the wants and needs of the people, and how they are being able to be empowered through active anticipation and urban citizenship. Here spatial justice is defined as a process. (QPIRG-Concordia, 2012)0

\section{PARTICIPATORY PLANNING PROMOTING SPATIAL JUSTICE}

Participatory planning manifests the right to voice, right to difference and the right to the city for all, an opportunity for the people to be heard and shape their lives. An urgent need especially for the least advantaged groups who are unlikely recognized through the normal analytic procedures and information sources of bureaucrats, legislative officials and planners. Traditionally these groups are submerged in a culture of powerful political structures and institutions where community inputs are often put to a form of tokenism. As it is often argued when the voice of the voiceless groups is heard, urban plans are likely to succeed in achieving equity and efficiency. (QPIRG-Concordia, 2012)

Although public participation might be a difficult process to carry out, still if it is implemented efficiently and effectively it might serve a lot of benefits of justice;

- A tool for empowering citizens

- Elimination of domination and oppression

- Deepen democracy and increase sense of citizenship

- Works against centralization of decision-making

- Increase citizen satisfaction and trust in the outcome 
- Build citizen capacity

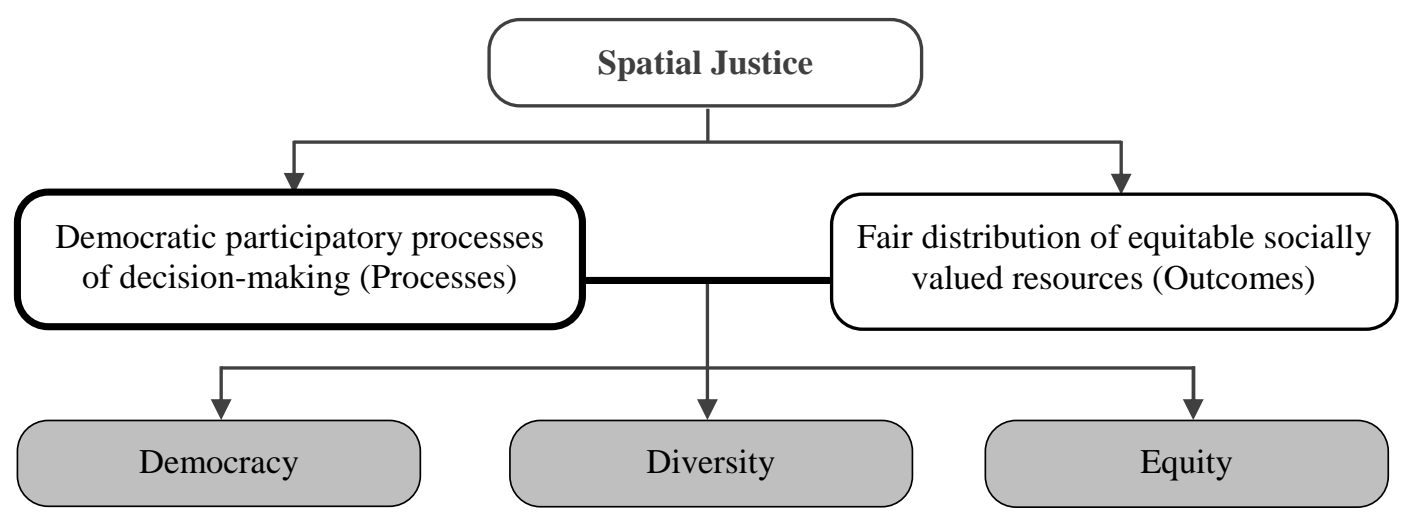

Figure 3, participatory urban planning processes approach to spatial justice (by Researcher, 2019)

\section{CRITERIA FOR ASSESSING THE PARTICIPATORY URBAN DEVELOPMENT PROCESSES AND OUTCOME}

In search for the just and democratic nature of the participatory planning processes, Agger and Lofgren (2008) proposed a theoretical framework for assessing the participatory processes through five main principles as shown in table 1 . They extracted these democratic norms from literature on communicative and collaborative planning processes and their potential outcomes.

Effectiveness of the participatory process can be defined, from spatial justice view, as the fair and democratic spatial outcomes of the participatory program in serving social justice for the affected local community. Finding a consistent set of effectiveness criteria is elusive. However, theory-based, the spatially just outcomes is interpreted in the fair and equitable redistribution of socially valued resources. Therefore, the intended vision is met when justice in social and spatial improvements are achieved. Adopting UCLA's Urban Planning Group search for a definitive criteria for spatial justice, they categorized it into three main principles; spatial claim, spatial power and spatial link (table 2). (Bassett, 2013) 
Table 1. Agger and Lofgren's theoretical framework for democratic participatory planning processes

\begin{tabular}{|c|c|c|}
\hline Principle & Norm & Process \\
\hline \multirow[t]{3}{*}{ Access } & Equal access & - Equal access to processes with no biases to a certain group \\
\hline & Inclusion & $\begin{array}{l}\text { - Access for all to processes and to information } \\
\text { - Presence of local representatives }\end{array}$ \\
\hline & Transparency & $\begin{array}{l}\text { - Availability of information } \\
\text { - Awareness of participation goals }\end{array}$ \\
\hline \multirow[t]{4}{*}{$\begin{array}{l}\text { Public } \\
\text { deliberation }\end{array}$} & Openness & $\begin{array}{l}\text { - Clear stakeholder analysis } \\
\text { - Involve different stakeholders } \\
\text { - Early involvement }\end{array}$ \\
\hline & Tolerance & - Encourage all participants in tolerant communication \\
\hline & $\begin{array}{l}\text { Efficient } \\
\text { dialogue }\end{array}$ & - Productive dialogues \\
\hline & $\begin{array}{l}\text { right for } \\
\text { participation }\end{array}$ & $\begin{array}{l}\text { - Participants voices included in decision-making } \\
\text { - Consensus building }\end{array}$ \\
\hline \multirow[t]{2}{*}{$\begin{array}{l}\text { Democratic } \\
\text { Adaptability }\end{array}$} & Continuity & $\begin{array}{l}\text { - Flexibility of the participatory process } \\
\text { - Stability of citizen involvement } \\
\text { - Adaptable to handle any conflicts }\end{array}$ \\
\hline & Competence & - Learning and social capital sustained \\
\hline Accountability & Reliability & - Hold public-authorities responsibility for their actions \\
\hline \multirow{3}{*}{$\begin{array}{l}\text { Development } \\
\text { of political } \\
\text { identities }\end{array}$} & Empowerment & - Practice of identity representation \\
\hline & Endowment & - Develop capabilities of actors involved \\
\hline & $\begin{array}{l}\text { Development } \\
\text { of political } \\
\text { identity }\end{array}$ & $\begin{array}{l}\text { - Social capital-trust building through communication } \\
\text { - Political capital-ability to work collectively/engage in } \\
\text { diction-making }\end{array}$ \\
\hline
\end{tabular}

Table 2. Criteria for spatially just outcomes

\begin{tabular}{|c|c|}
\hline Principles & Description \\
\hline Spatial Claim & The ability to live, work, or experience space \\
\hline Spatial Power & Opportunities to succeed in and contribute to space \\
\hline Spatial Links & Access and connect to and with other spaces \\
\hline
\end{tabular}

\section{EXAMPLE 1: MEDELLIN, COLUMBIA}

Medellin is the second largest city in Columbia. One of the most urbanized countries in Latin America characterized by the unequal distribution of land, resources and opportunities. By the end of the twentieth century, the city underwent a process of declination and was considered one of the most violent cities in the World. The city adopted new ways of urban development and management, after being known as the 'murder capital 
of the World', in 2013 the city was awarded the most innovative city by the Urban Land Institute (ULI). Hosting the 7th session of the World Urban Forum in 2014 allowed the city of Medellin to showcase its creative approaches for a better city, linking the poorer peripheries to the city center and enhancing the quality of life in the city. (Ferrari et al, 2018)

\subsection{The PUI Model}

As a result of the government's failure to face the rapid urbanization, $50 \%$ of the population lived in the peripheries, suffering from deprivation and socio-spatial exclusion. In 2005, the local administration adopted a new urban development strategy 'Social Urbanism'. It combined both, urban development interventions through participatory processes, and social/institutional programs (cultural, educational, employment, etc.) that compliment the physical change. Based on this strategy, the Urban Integrated Plan-PUI Model (Proyecto Urbano Integral) was developed and applied to 8 communes. It consisted of three main components, as shown in table 3.

Table 3, the three components of the PUI Model

\begin{tabular}{|c|c|c|}
\hline \multirow{2}{*}{ Institutional } & \multirow{2}{*}{ Coordination } & Inter institutional coordination \\
\hline & & Inter-sectorial coordination \\
\hline \multirow{4}{*}{ Social } & \multirow{4}{*}{$\begin{array}{l}\text { Community participation } \\
\text { and communication }\end{array}$} & Identifying \\
\hline & & Validating \\
\hline & & Participation \\
\hline & & Education \\
\hline \multirow{9}{*}{ Physical } & \multirow{3}{*}{ Public space and mobility } & Construction of new public spaces \\
\hline & & Improvement of Existing public spaces \\
\hline & & Improvement of mobility \\
\hline & \multirow{3}{*}{ Housing } & Construction of new houses \\
\hline & & Improvement of existing housing \\
\hline & & Legalization of tenure \\
\hline & \multirow{2}{*}{ Community facilities } & Improvement of community facilities \\
\hline & & Construction of community facilities \\
\hline & Natural environment & Improvement of natural environment \\
\hline
\end{tabular}

\subsection{The PUI Model participatory processes}

The process started with identification of stakeholders and invitation of all community representatives, in order to involve all in the project. Information was gathered through public meetings with the community, existing database, quantitative and qualitative field surveys and workshops known as 'Tallere de Imaginaries Urbanos' (fig. 3). The openness of the process brought back the trust of the people towards the local administration. Based on the dialogue with the community, workshops and site visits, problems and opportunities were analyzed and projects locations were identified. Inter-institutional agreements in the diagnosis stage are made with all the institutions and agencies of the local administration, an 
agreement of contribution and commitment based on the initial general plan of the project. This allowed a sustained relation between the government and those governed through out the project. Part of the success of the PUI model was the presence of a strong political will that was behind the development projects, committed to address in a significant way the complex problems present in the deprived neighborhoods. This allowed new institutional arrangements seen in the collaboration between different agencies of the municipality and the local communities. (Calderon, 2012)

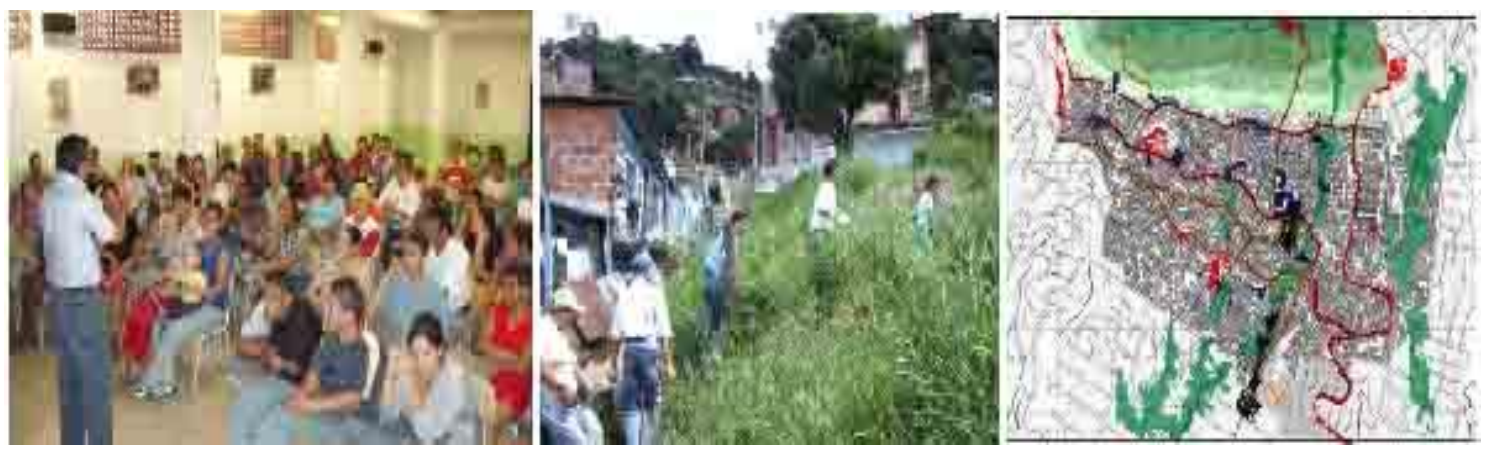

Figure 3, public meetings, filed surveys and mapping during the diagnosis stage of the PUI Model in Medellin

The team is responsible for the management, coordination and support of different actors and projects within the PUI program. This forms a decentralized management entity, which focus only on the project and the area. That guarantees and holds them a direct responsibility for the program process and outcomes. Based on the wide range of problems present in this informal area, one of the PUI model's main objectives is to empower the community-based organizations. Through training community leaders and creating urban activities and spaces, the community were able to develop designs decisions concerning their community, supervise and evaluate the implementation of the development projects through deliberative and collaborative processes.(Calderon,2012)

\subsection{The PUI Model urban development outcomes}

The main vision for the PUI model was to give back the city to its inhabitants and the inhabitants back to the city. It was only possible by rebuilding the fabric of the city that was under prolonged years of violence and by empowering the individuals. It focused on developing the poorest areas and fighting against inequalities with social inclusion and improvement of citizenship. The model's intervention was mainly manifested in the following:

- Spatial Claim: Juan Bobo re-housing project that received a Best Practice Award for housing in 2013, Security of land tenure for 223 dwellings

- Spatial power: 290 social development programs included healthcare, education, employment, 200,000 $\mathrm{m}^{2}$ of public spaces were built, Library-parks for culture and education reform, extension to public spaces, $16,000 \mathrm{~m}^{2}$ of public facilities providing the community with different services

- Spatial link: The Metrocable project linking three informal settlements with the main transit system, solar -powered escalators and stairs facilitating mobility in the rough steep geographies, newly paved street, pedestrian paths and bridges increasing connectivity. 


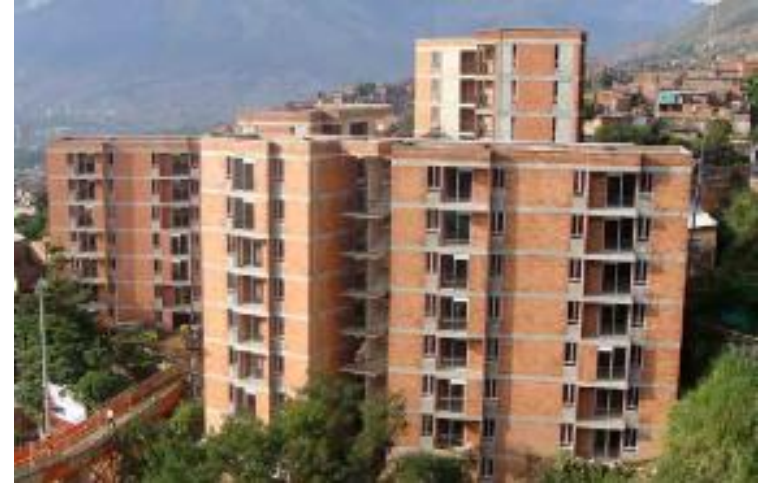

Figure 4, Juan Bobo re-housing project

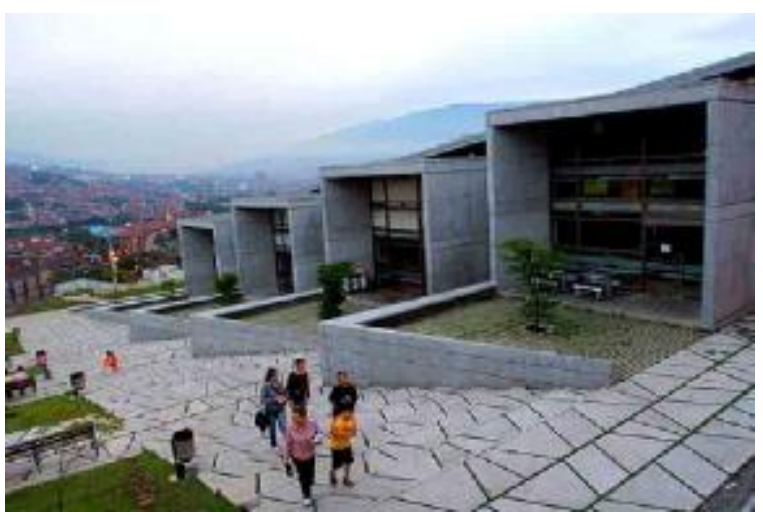

Figure 6, library-parks

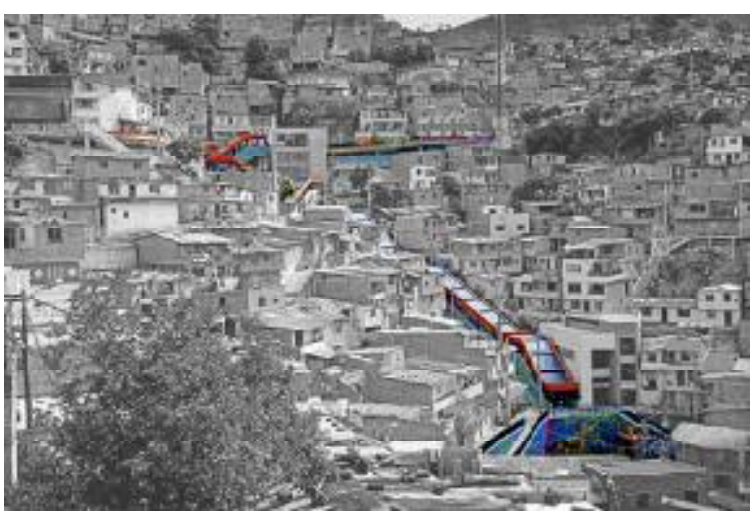

Figure 8, escalators and stairs

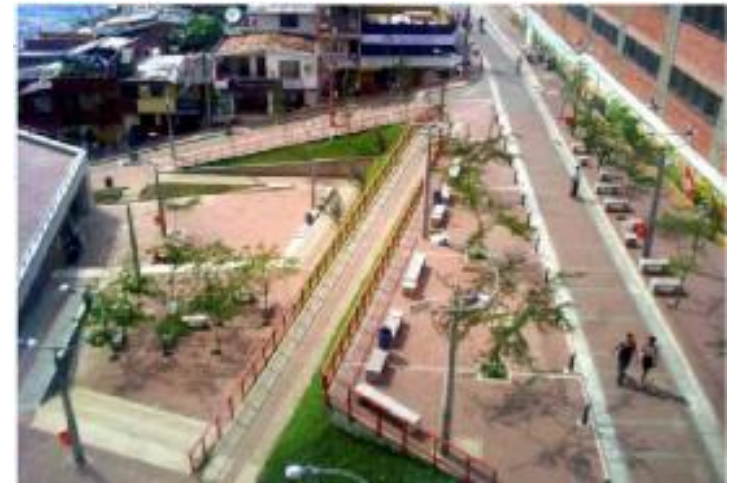

Figure 5, public spaces
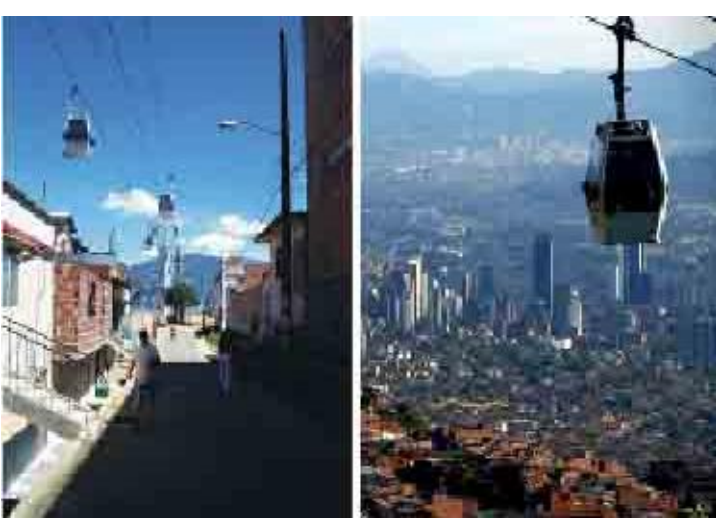

Figure 7, the new Metrocable

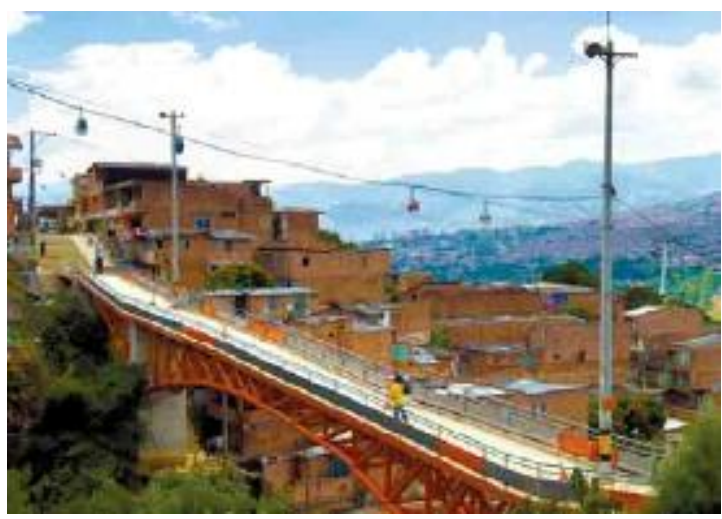

Figure 9, pedestrian bridges

\section{EXAMPLE 2: BANGKOK, TOKYO}

Bangkok, the capital of Thailand, is a fast growing city due the rapid immigration from rural to urban areas. The city is facing pressures on urban management. Gentrification forces occur in the central districts and today many communities are excluded from access to resources and services forced to move and locate in houses spatially and economically disconnected from the urban center. Thus, the power seems to be applied rather than shared, contributing to further pockets of segregation. (Hunter, 2011) 


\subsection{Baan Mankong Model}

It is a successful 'self-aid program implemented by the Community Organizations Development Institute (CODI) in 2003, an organization that works under the Ministry of Social development and Human Security. The program is a people-driven development program where the people in the community networks are the main actors and solution finders, while the government acts as an enabler rather than a delivery institution. The program started with 10 pilot projects and scaled up, with a target of 2000 poor communities in 200 Thai cities. The poor communities work in collaboration with the local government, professionals, universities and NGOs in the development process. When development plans are finalized, the CODI channels flexible infrastructure subsidies and housing loans direct to the communities, which collectively plan and carry out improvements using budgets, which they manage themselves. (Cho, 2013)

\subsection{The Baan Mankong Participatory Processes}

This model differs from the previous PUI model in terms of access, as the communities has to apply first for the program and prove they are sufficiently organized to drive interventions before they can join the program. Although this requirement of community organization may exclude many poor communities, yet it guarantees the success of the program, enhances community ties and the feeling of ownership. The people establish 'saving groups' to try to afford the development of their community, building a sense of ownership. Each intervention is negotiated directly with the community with the help of professional and experts. Community architects employ planning workshops (fig. 10) with the locals to teach them the basics and only work as consultants rather than designers. The locals, defining their needs, carry out proposals and a final plan is elected that suits all members of the community. (Cho, 2013)

The imbalance of the resources of the participating residents across the same community were resultant barriers that stalled the program progress and prevented it from reaching the scale that CODI planned to reach. Additionally, The program is largely affected by the frequent power shifts in the political arena, yet the strength of the program lied in its continuous struggle of overcoming these shifts. There is still a need for a clear definition of the roles and responsibilities of the different actors in the program. It is an essential to increase accountability and promote good governance. Overall the program was an empowering tool for the people; they control and partly fund the resources, plan and negotiate solutions for the development of their community. Additionally, the process of surveying provides opportunities for the fragmented households to come together, meet and learn about each other's problems and establish collective power between them. The ability to develop common perspectives signifies the effectiveness of the collective community empowering process. The Program also has given the communities tremendous capacity of negotiation. They learned how to collect data that enhances their power to negotiate with different actors, how to organize themselves and be represented through their community actors. (Simpson, 2013; Dhabhakabtur, 2017)

\subsection{The Baan Mankong urban development outcomes}

The project's main focus was housing and ensuring good environments. Although the Baan Mankong program outcomes goes beyond the physical and social improvement of the upgrading process outcomes, yet the physical outcome of the process was more importantly to the community residents rather than the social outcomes. As they take loans to finance their community development and the quality of the resultant outcomes are what they are expecting. Still, the program was a success in enhancing leadership and ownership. There 
were several types of upgrading of the urban environment. Either through on-site upgrading or re-blocking or reconstruction, or through land sharing or relocating to another site with secure tenure within 5 kilometers of the original site. The CODI provided loans for land securing and for housing. It also provided subsidies for infrastructure and subsidies for supporting the process. (Archer, 2012)

-Spatial Claim: Housing units were built using the community collective power (fig. 11)

Securing land tenure (ex. Bang khen), yet in other cases people relocated to close areas -Spatial power: Limited public spaces were created with limited resources

-Spatial link: Building and improving vehicular and pedestrian paths, ex, Klong khen where the housing units were relocked to create path across the canal (fig. 13)

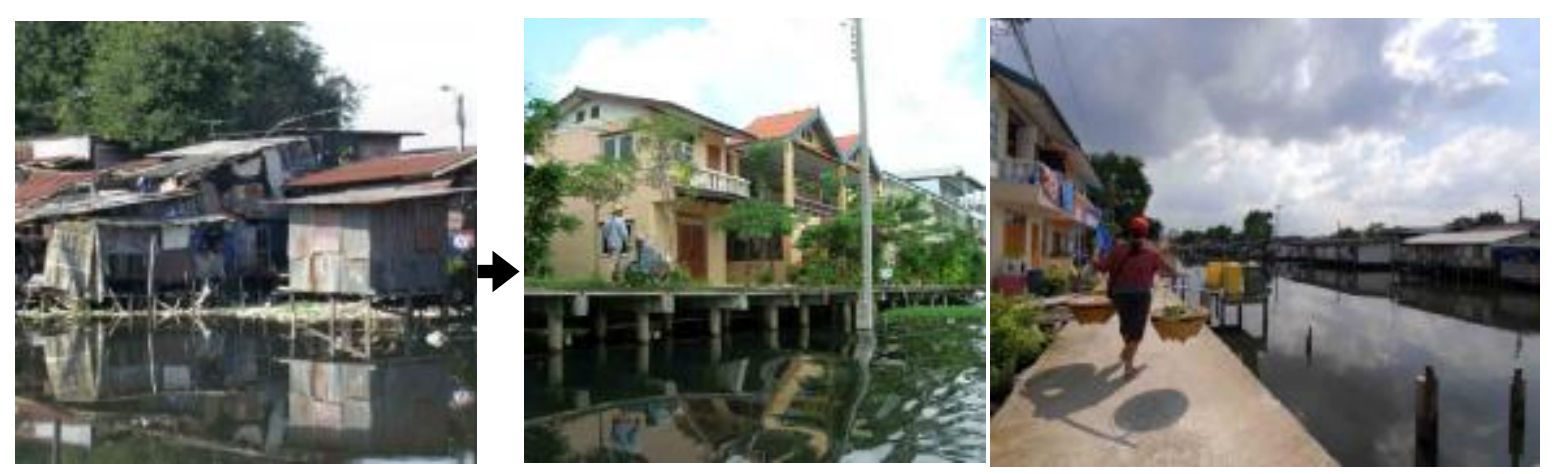

Figure 11, Klong Khen before and after Baan Mankong program

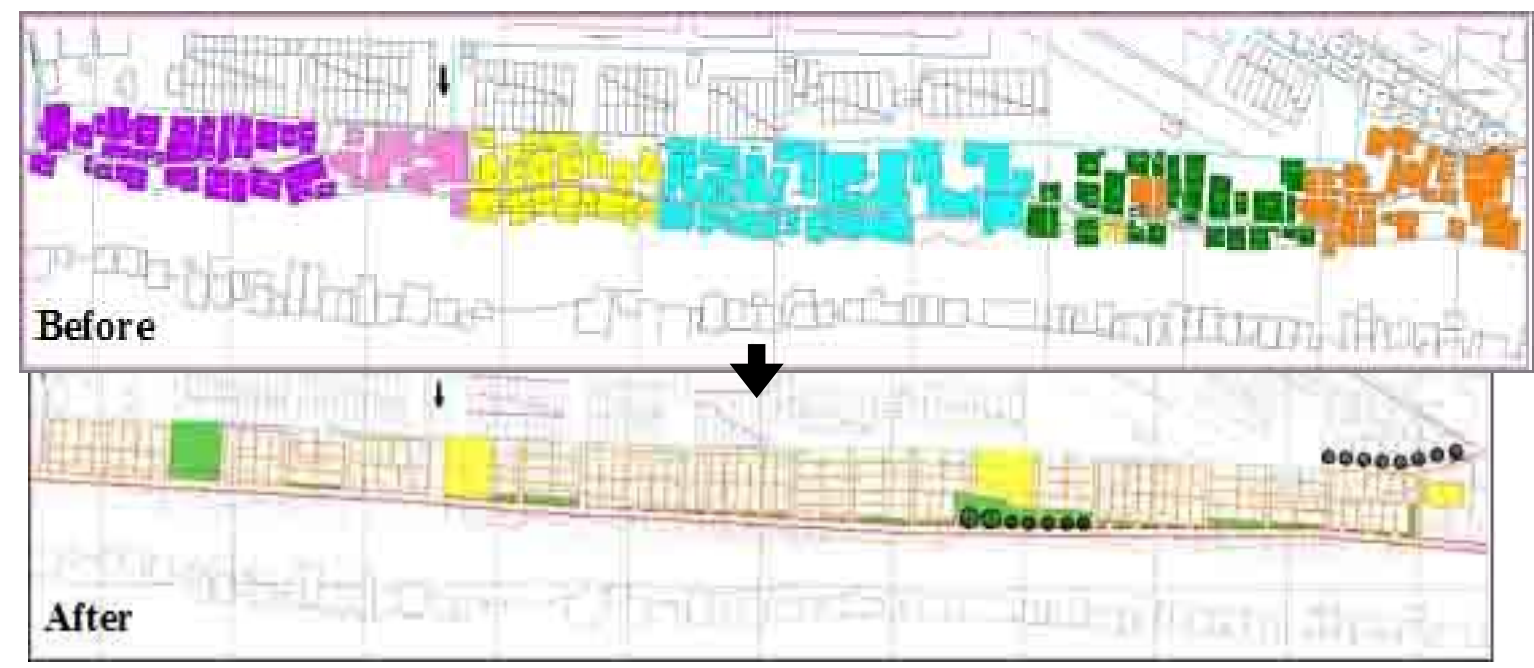

Figure 13, Klong Khen re-blocking housing units create new corridors and open spaces

\section{Case study: Cairo, Egypt}

Cairo where a participatory urban development program was carried, is selected for the study. Cairo is the capital of Egypt and by far the most populous city in the country. According to the 2006 census the Egyptian population is approximately 73 million inhabitants, local experts unofficially adds 20 million more to the current population, where nearly a quarter of it lives in Cairo. As the principal city, the centralization of the country's economic and political life as well as most of the Egyptian industry and most of the jobs are located in Cairo, lead to the massive migration from rural areas to Cairo in search for jobs, mostly located in informal settlements in the city peripheries. It was until the 1990s that the government interventions for upgrading unplanned urban poor areas where mainly top-down strategies. In 1994, the government initiated a new bottom-up program with the German 
Government, for upgrading urban poor areas where community participation is the main focus of the program. (Howeidy, et al., 2009)

\subsection{GIZ-PDP in Ezzbet El Nasr}

In 1998 the Arab republic of Egypt signed a program agreement with the Federal Republic of German, The Participatory Urban Management Program (PUMP), later was called the Participatory Development Program (PDP). The GIZ was to provide the Egyptian government with policy advice on how to apply participatory methods for the development of urban poor areas. Also the German program provided financial support, for the first phases of the project, under the responsibility of the Reconstruction Credit Institute known as KFW (Kreditanstalt Fur Wiederaufbau) - the German Government-owned bank in Frankfurt - in cooperation with the Egyptian Ministry of Economic development (MoPIC) and the German Federal Ministry of Economic Cooperation and Development (BMZ). In the final phase, the projects were funded by the European Union (EU), corresponding to the GIZ, Bill and Melinda Gates Foundation and the MoPIC. (Hanna, 2014)

The PDP was one of the first participatory planning initiatives in Egypt that combined both technical and financial support. The PDP was implemented by the GIZ in cooperation with the Ministry of Housing, Utilities, and Urban Communities (MOHUUC), and the three Governorates of Greater Cairo Region; Cairo, Giza and Qalyubeya. Two pilot projects were selected for the implementation of the participatory development; Manshiet Nasser in Cairo and Boulaq El Dakrour in Giza. The GIZ-PDP did not intervene in areas where relocation is needed for development; it contributed in areas of on-site redevelopment. Currently, it works in 9 areas in the Greater Cairo Region governorates (Cairo, Giza and Qalyubeya); the Ezzbet El Nasr, Ain Shams and Massaken Geziret El Dahab, Markaz El Abhath/El Warraq, Old Boulaq, El Matariya, Khossoos, Khanka, Qalyub. (The World Bank, 2019; Hanna, 2014)

Table 4, the GIZ-PDP implementation process phases

\begin{tabular}{|c|c|c|c|}
\hline \multicolumn{4}{|c|}{ GIZ-PDP implementation process } \\
\hline $\begin{array}{c}\text { 1st Phase } \\
(1998-2003)\end{array}$ & $\begin{array}{l}\text { 2nd Phase } \\
(2004-2007)\end{array}$ & $\begin{array}{c}\text { 3rd Phase } \\
(2008-2011)\end{array}$ & $\begin{array}{l}\text { Last Phase } \\
(2011-2018)\end{array}$ \\
\hline $\begin{array}{l}\text { Scaling up: } \\
\text { - Technical support to } \\
\text { include the } \\
\text { government level } \\
\text { - Two pilot projects } \\
\text { Boulaq El Dakrour and } \\
\text { Manshiet Nasser }\end{array}$ & $\begin{array}{l}\text { Exploration of: } \\
\text { - The area } \\
\text { - The local } \\
\text { stakeholders } \\
\text { Measure the potential } \\
\text { of participating the } \\
\text { local communities }\end{array}$ & $\begin{array}{l}\text { Tools on the local } \\
\text { level: } \\
\text { - Knowing local } \\
\text { community } \\
\text { - Support local initiatives } \\
\text { - Information sharing } \\
\text { - Participatory planning } \\
\text { Budgeting }\end{array}$ & $\begin{array}{l}\text { - Improve living } \\
\text { conditions } \\
\text { - Implementation in } 9 \\
\text { selected areas - } \\
\text { Participatory } \\
\text { processes } \\
\text { - Improve management } \\
\text { at government level }\end{array}$ \\
\hline
\end{tabular}

Ezzbet El Nasr, also known as Torab El Yahud (The Jewish Cemetery), is an unplanned selfbuilt settlement in El Basateen district in the south of Cairo. It is located $8 \mathrm{~km}$ away from the historic center and $4 \mathrm{~km}$ from the Nile River. The area was originally planned as an industrial area on the outskirts of Cairo. But then, with the urban expansion of Cairo, it became part of the city next to formally planned areas. It is bounded by the intersection of two main highway roads; the Ring Road in the South and the Autostrad Road in the East. The Jewish cemetery bounds the area from the West and a slaughterhouse in the North. The area covers 55 hectares ( 0.55 Kilometers squared) on state-owned land, where the urban fabric covers 30 hectares and the remaining land is occupied by the Jewish cemetery, a mothballed sewage treatment plant and 6 hectares paved area that has been previously used as a bus depot and a used car market. Ezzbet El Nasr has approximately 72 thousand inhabitants living inside it. (TU Berlin, 2010; by Researcher, 2019) 


\subsection{SWOT analysis of Ezzbet EI Nasr before the GIZ-PDP}

Table 5 shows the SWOT analysis for the area of Ezzbet El Nasr before the GIZ-PDP intervention in 2011. The analysis reveals higher percentages of the weaknesses and threats found in the area. (TU Berlin, 2010)

Table 5, Ezzbet El Nasr SWOT analysis before the GIZ-PDP

\begin{tabular}{|c|c|c|c|}
\hline Strengths & Weaknesses & Opportunities & Threats \\
\hline $\begin{array}{l}\text { Strategic location } \\
\text { near city center and } \\
\text { connected to two } \\
\text { main roads } \\
\text { Economic activities } \\
\text { like stone carving, } \\
\text { car-repair shops, } \\
\text { and other small } \\
\text { businesses } \\
\text { Schools compound } \\
\text { within walking } \\
\text { distance from most } \\
\text { edges of the area, } \\
\text { well equipped }\end{array}$ & $\begin{array}{l}\text { Accessibility and } \\
\text { mobility due to } \\
\text { insufficient access } \\
\text { to the area, lack of } \\
\text { sufficient number of } \\
\text { pedestrian tunnels, } \\
\text { unpaved streets, } \\
\text { waste blockage, and } \\
\text { sewage flooding, no } \\
\text { public } \\
\text { transportation } \\
\text { Lack of services, } \\
\text { especially health } \\
\text { care facilities, no } \\
\text { central market, no } \\
\text { recreational areas }\end{array}$ & $\begin{array}{l}\text { Vacant Lands } \\
\text { available for any } \\
\text { development } \\
\text { projects } \\
\text { Interested NGOs in } \\
\text { developing the area }\end{array}$ & $\begin{array}{l}\text { Insecure land tenure as the } \\
\text { area is on state-owned land } \\
\text { Lack of proper infrastructure } \\
\text { for electricity, sewage and } \\
\text { wastes disposal systems } \\
\text { Health threatening } \\
\text { environment due to sewage } \\
\text { and wastes accumulated in } \\
\text { the streets, smoke from } \\
\text { burning garbage outside the } \\
\text { handling station found in the } \\
\text { area, no greenery, no natural } \\
\text { sunlight access to housing } \\
\text { units due the dense urban } \\
\text { fabric } \\
\text { Lack of safety and security } \\
\text { due to absence of police } \\
\text { station, insufficient lighting } \\
\text { of streets and corridors, } \\
\text { presence of thugs } \\
\text { High unemployment rate }\end{array}$ \\
\hline
\end{tabular}

\subsection{The GIZ-PDP Participatory Process}

One of the main tools of the program was the Participatory Needs Assessment (PNA), as to accomplish the program's strategy of fair representation of all community members and stakeholders. he PDP in Ezzbet El Nasr subcontracted a consultancy firm, the Center for Development Services (CDS) to conduct PNA. A total of 46 Focus Group Discussions and 34 Key Informant Interviews were carried out with the neighborhood's men, women and youth from the age of 18 to 35 (fig 14). Depending on the interviews and site surveys the community top priority needs and problems were identified as follows (Center for Development Services, 2013):

- Lack of hospital/medical clinic in the area

- Lack of security due to absence of official authorities and insufficient lighting of streets and corridors

- Lack of public transportation due to unsaved streets and no bus stops

- Unavailability of natural gas infrastructure in the area

- High unemployment rate due to poor education and poor skills

- Poor serviced infrastructure

- Large amount of solid wastes and poor garbage collection

Afterwards decisions were taken by authorities on the development projects to be implemented. According to Arnstein's ladder participation, the locals are considered as information provider and consultants; where their views and opinions are heard but they do not take part in decision-making. Thus, their participation is identified as the second degree 
of tokenism. The priorities of the community are not directly transferred into projects but they are considered as input for a higher decision-making round. Some of the other draw backs participation process that the program didn't reach a lot of community residents, the PNA too a long time than it, should which made the locals lose interest in participating and lose trust in the program representatives. On the other hand, the participation process was open for everyone to join, the participants states that the dialogue was efficient and they get empowered. (Hanna, 2014; interviewed residents, 2019)

The program also established, Local Area Dialogue Committees (LADCs) through the establishment of civil entities in order to mobilize community self-management, yet afterwards the authorities banned these type of gatherings for national security reasons. As a part of institutionalization support, the PDP worked on capacity building by establishing Urban Upgrading Units (UUU) in national and local concerned governments. The PDP equipped these units with the necessary tools and trainings like the usage of GIS techniques. On the Public day in Ezbet El Nasr (fig 15), the GIZ representatives presented the PNA results and the action plan. (Center for Development Services, 2013)0

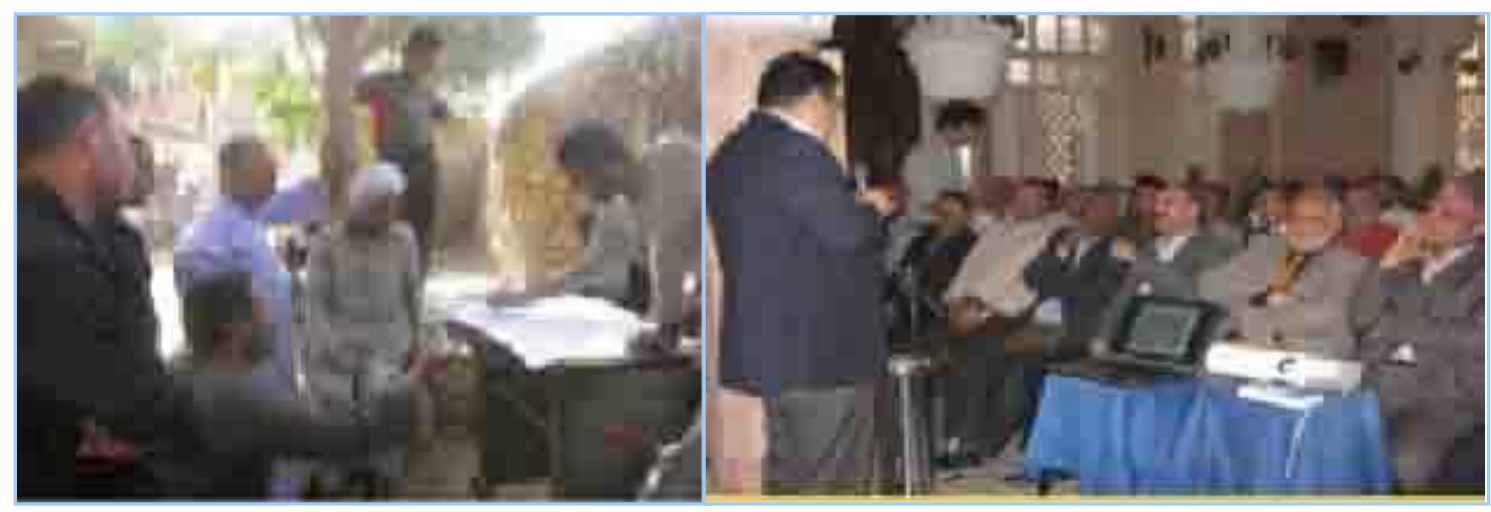

Figure 14, CDS researcher developing community map with the locals
Figure 15, GIZ-PDP representative introducing the program to the locals

\subsection{GIZ-PDP Development Outcomes}

The GIZ and PDP has implemented several development projects the authorities have agreed upon according to the needs of the locals, beside funding social programs that complement the physical change. While the locals felt satisfied with the transformation and improvement of their area, yet there are still other problems that were identified in the PNA that are still unresolved. In terms of spatial justice, the implemented projects were analyzed as shown in the following section. (Interview with GIZ-PDP representatives, 2019)

-Spatial Claim: Installing proper infrastructure

Paving and lighting of streets

New public space and playground

A new Medical Center providing the locals with affordable health care services

- Spatial power: Installing 260 rooftop farming tables for 46 households with the coordination of Shaduf with the community residents

Public environmental awareness seminars and climate change

LED lighting of streets, pedestrian tunnel, the Youth Center, and the school

Provided more than 1000 household with energy-efficient light bulbs

Installing 30 solar heating units in service facilities, 5 of which are found in the Youth Center Planting water efficient trees in the area's streets, corridors, the new bus station and the Youth Center 
Building human capacity through social programs; like professional training workshops for men and woman developing their working skills, improving education in the schools

- Spatial link: Identifying Ezzbet El Nasr with the first sign pinpointing the area and installing streets name signs with cooperation of the Youth Network of Ezzbet El Nasr

New Ezzbet El Nasr entrance in the Northwest of the area extending from EL Gazaer Road improving accessibility

Improved mobility and walkability through street paving and the inner corridors

A new bus station equipped with a room for the superintendent and sheltered waiting area and providing 10 seminars for the community awareness on traffic safety, health and environment.
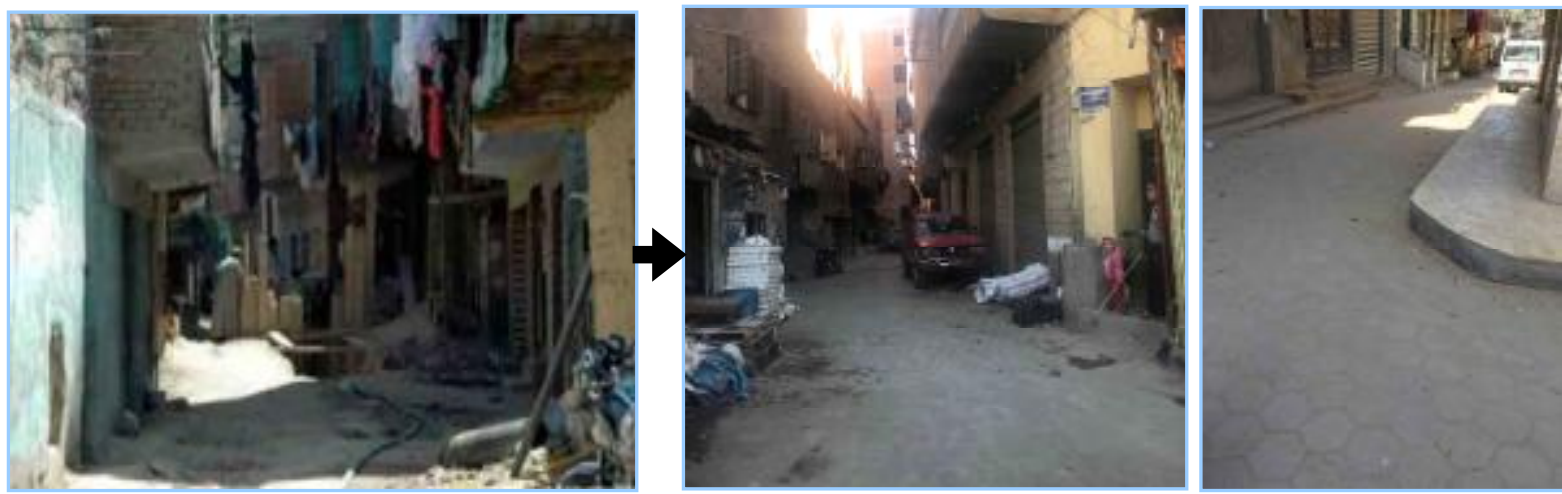

Figure 16, Ezbet el Nasr before and after paving of street and installing proper infrastructure

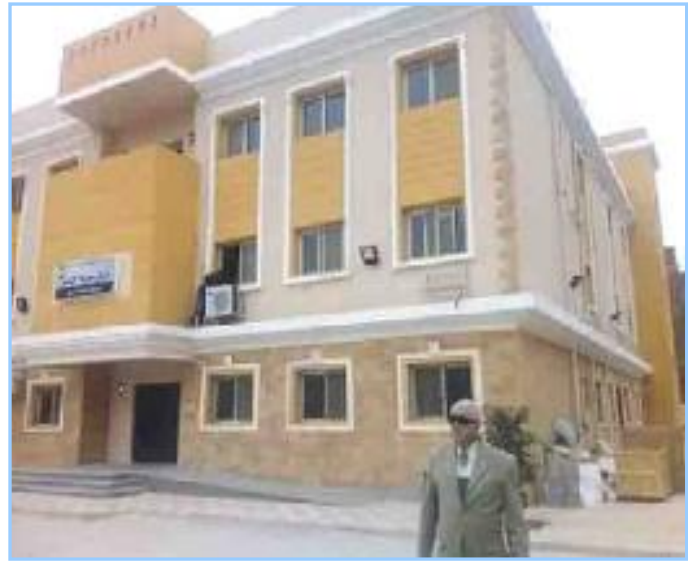

Figure 17, the new medical center

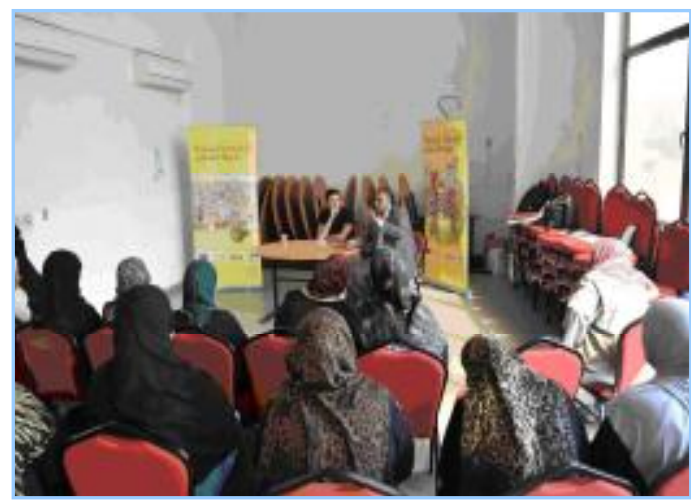

Figure 19, Community awareness seminars

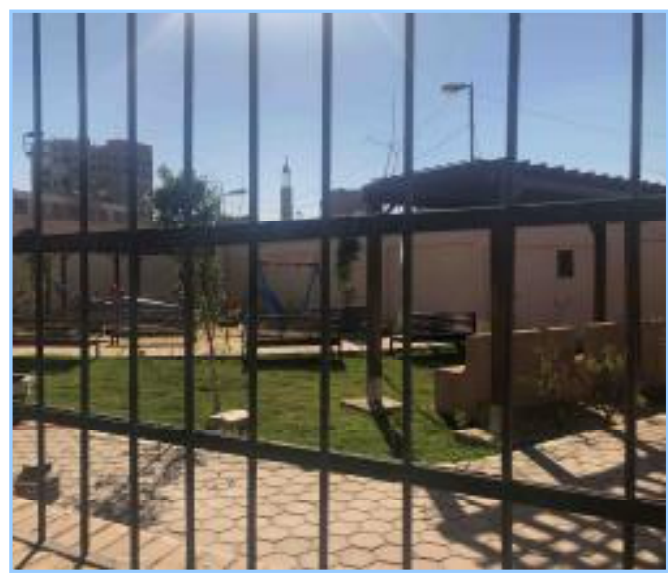

Figure 18, new public space and playground

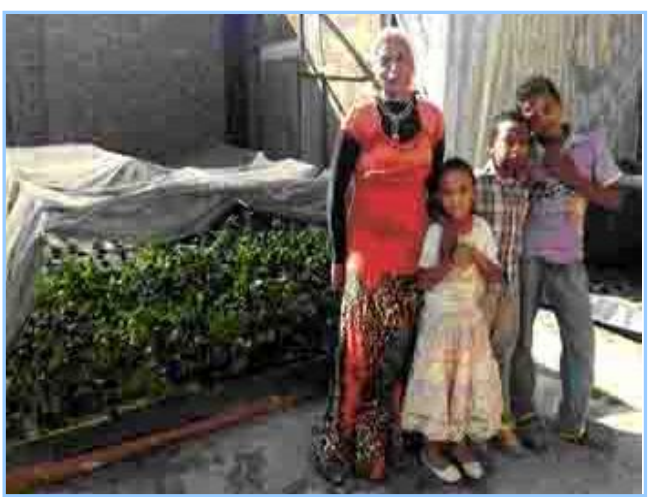

Figure 20, rooftop farming by locals 


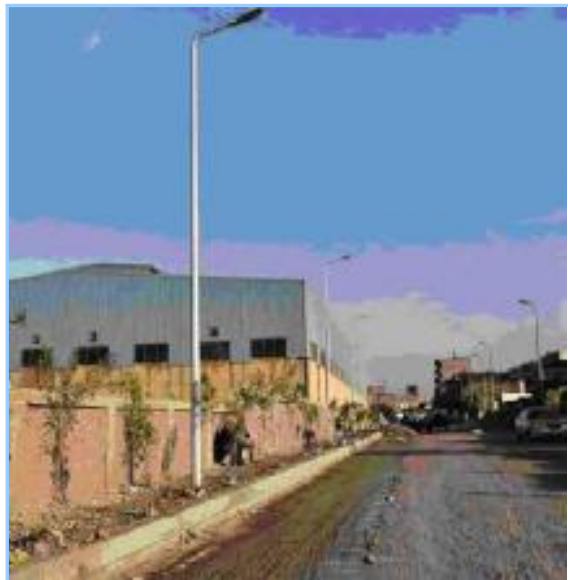

Figure 21, new entrance

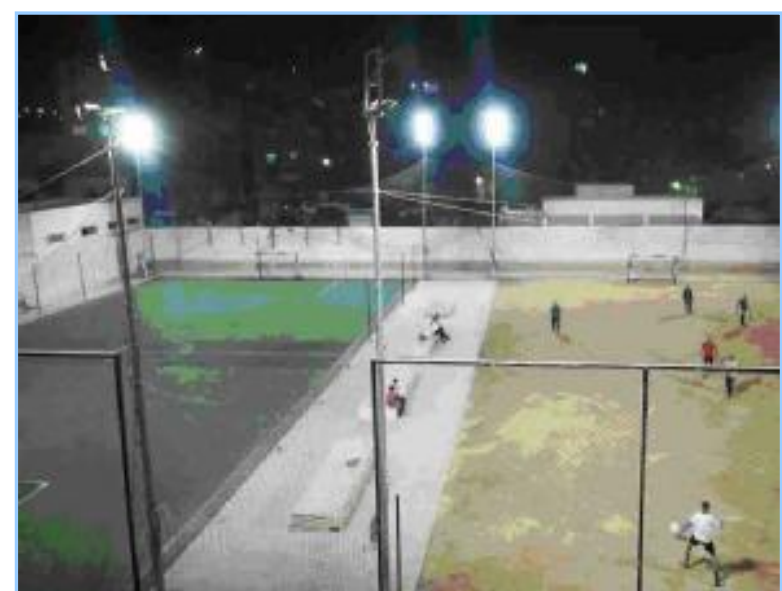

Figure 22, installing LED lighting in youth center

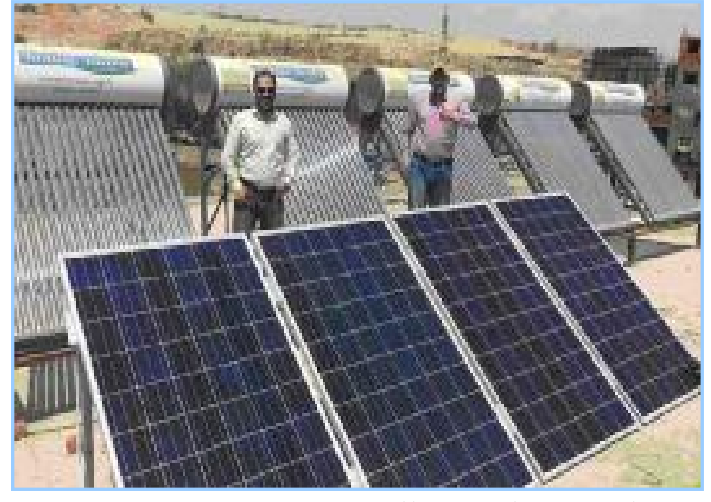

Figure 23, Installing Solar panels

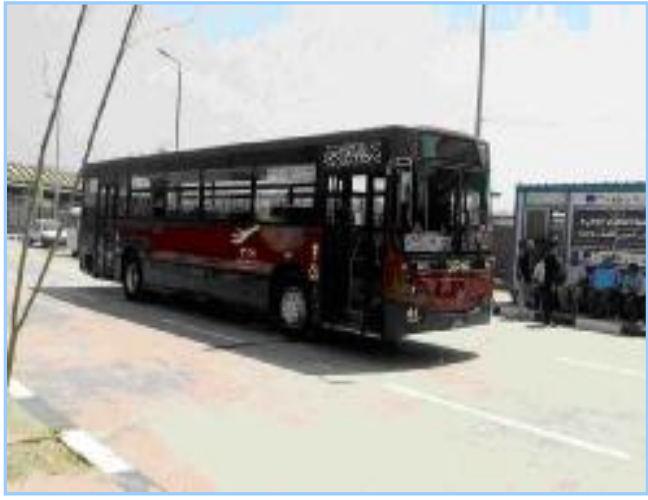

Figure 24, the new bus station

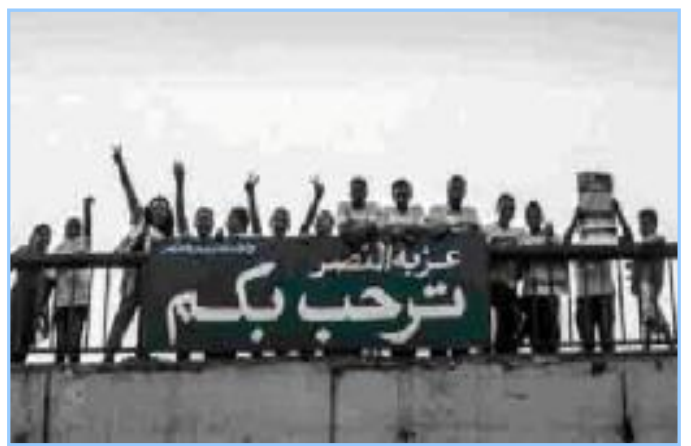

Figure 25, Installing the first sign identifying the area with cooperation of the Youth Network of Ezzbet El Nasr

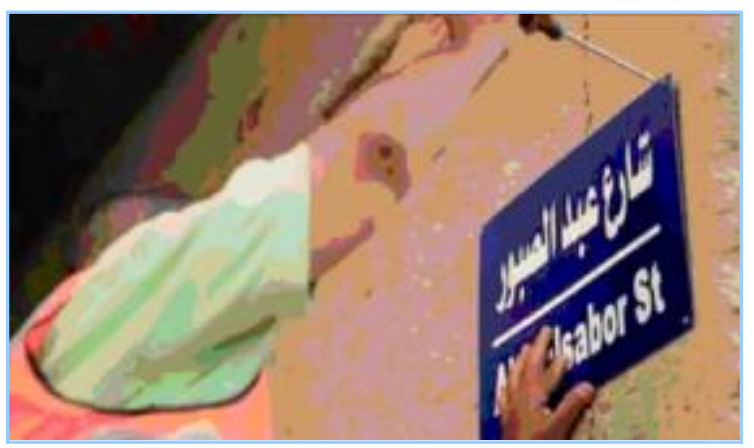

Figure 26, installing street name signs 
12. COMPARISON BETWEEN THE PUI MODEL, BAAN MANKONG AND THE GIZ-PDP

\begin{tabular}{|c|c|c|c|c|}
\hline & & $\begin{array}{l}\text { Medellin- } \\
\text { PUI Model }\end{array}$ & $\begin{array}{c}\text { Bangkok- } \\
\text { Baan } \\
\text { Mankong }\end{array}$ & $\begin{array}{c}\text { Cairo } \\
\text { PDP-GIZ }\end{array}$ \\
\hline Location & Continent, Country & $\begin{array}{c}\text { South } \\
\text { America, } \\
\text { Columbia }\end{array}$ & Asia, Thailand & Africa, Egypt \\
\hline \multirow[t]{2}{*}{ Model Scale } & Community/District & District & Community & Community \\
\hline & Access & For all & $\begin{array}{l}\text { For all upon } \\
\text { approval }\end{array}$ & For all \\
\hline \multirow{5}{*}{$\begin{array}{l}\text { Participatory } \\
\text { Process }\end{array}$} & Public deliberation & $\begin{array}{l}\text { Yes except } \\
\text { for initial } \\
\text { planning }\end{array}$ & Yes & Yes \\
\hline & Democratic adaptability & Yes & Yes & Yes \\
\hline & $\begin{array}{l}\text { Development of political } \\
\text { identities }\end{array}$ & Yes & Yes & No \\
\hline & Accountability & $\mathrm{No}$ & No & No \\
\hline & Participatory budgeting & No & Yes & No \\
\hline \multirow{6}{*}{$\begin{array}{l}\text { Social } \\
\text { Outcomes }\end{array}$} & Equity & Yes & Yes & Yes \\
\hline & Social inclusion/diversity & Yes & Yes & Yes \\
\hline & Democracy & Yes & Yes & Yes \\
\hline & $\begin{array}{l}\text { Social } \\
\text { Cohesion/Community } \\
\text { capacity }\end{array}$ & Yes & Yes & Yes \\
\hline & Empowerment/Ownership & Yes & Yes & Yes \\
\hline & Security & Yes & Yes & No \\
\hline \multirow[t]{8}{*}{$\begin{array}{l}\text { Spatial } \\
\text { Outcomes }\end{array}$} & $\begin{array}{l}\text { Spatial inclusion/City } \\
\text { integration }\end{array}$ & Yes & No & Yes \\
\hline & $\begin{array}{l}\text { Accessibility/physical } \\
\text { connectivity }\end{array}$ & Yes & Yes & Yes \\
\hline & Access to decent housing & Yes & Yes & No \\
\hline & Land tenure & Yes & Yes & No \\
\hline & Urban infrastructure & Yes & Yes & Yes \\
\hline & Service facilities & Yes & Yes & Yes \\
\hline & Public spaces & Yes & Limited & Limited \\
\hline & $\begin{array}{l}\text { Quality of communal } \\
\text { spaces }\end{array}$ & High & Low & Medium \\
\hline
\end{tabular}

\section{CONCLUSION}

Based on the analysis of the process and the outcomes of the GIZ-PDP participatory urban development program in Egypt, and comparing it to two international examples, it can be concluded the following; The project's implementation was challenged by the limitation of the community participation; level of participation was limited to consultation while the final decisions were taken by the authorities and practitioners. The program in the beginning took a longer time than expected where the residents lost interest in engaging in the project's activities. In addition, the program did not develop enhanced tools and methods that suit the Egyptian urban poor mentality, and that encourage participation of the whole community. The lack of strong will and commitment to participatory approaches in the state policy toward urban development of urban poor areas is apparent in the limited number of development 
projects, also in the absence of maintenance and follow-up on these projects, and the weak commitment to fulfilling community needs. On the other hand, the program triggered a sense of citizenship and participation empowered the local residents. Life for many people living in the area has dramatically changed for the better. The social and spatial transformation although it was limited, yet it is considered a first step toward more democratic and just practices in urban planning in Egypt, ensuring the right to the city for everyone.

\section{REFERENCES}

1- Agger, A., \& Lofgren, K. (2008). Democratic Assessment of Collaborative Planning Processes. Sage Publications , 7 (2), 145-164.

2- Archer, D. (2009). Social Capital and Participatory Slum Upgrading in Bangkok, Thailand. University of Cambridge.

3- Bssett, S. M. (2013). The Role of Spatial Justice in the Regeneration of Urban Spaces: Groningen, The Netherlands. University of Illinois.

4- Calderon, C. (2012). Social Urbanism: Integrated and Participatory Urban Upgrading in Medellin, Colombia.[online] Retrieved 2019, from https://www.researchgate.net/publication285322060_Social_Urbanism_integrated_and participatory_urban_upgrading_in_Medellin_Colombia

5- Center for Development Services. (2013). Participatory Needs Assessment in Informal Areas, Cairo Governorate. Cairo: PDP.

6- Cho, Y. (2013). Evaluation of the Baan Mankong Slum Upgrading Projects in Thailand. University of Cincinnati.

7- Dhabhalabutr, K. (2017). The Empowerment of the Slum inhabitant as a Primary Agent of Low-income Housing: The Case Studies of Sengki and Tawanmai Communities, Thailand 1980-2011. Melbourne: Melbourne School of Design.

8- Ferrari, S. G., Smith, H., Coupe, F., \& Rivera, H. (2018). City Profile: Medellin. Elsevier , 74, 354-364.

9- Hanna, J. M. (2014). Urban Goverance and Participation in Greater Cairo Region. Thesis (MSc), Graz Technical University.

10- Hunter, W. (2011, October 31). Decoding Bangkok's Pocket-Urbanization: Social Housing Provision and the Role of Community Architects [online]. Retrieved 2019, from https://archinect.com/features/article/25485248/decoding-bangkok-s-pocketurbanization-social-housing-provision-and-the-role-of-community-architects

11- Howeidy, A., Shehayeb, D. K., Goll, E., Abdelhalim, K. M., Sejourne, M., Gado, M., et al. Cairo's Informal Areas Between Urban Challenges and Hidden Potentials. Egypt: GTZ-PDP.

12- Martinez, M. (2010). The Citizen Participation of Urban Movements in spatial Planning: A Comparison Between Vigo and Porto. International Journal of Urban and Regional Research, 35 (1), 25-45.

13- QPIRG-Concordia. (2012, August 15). Right to the city mtl [online]. Retrieved 2019, from Wordpress: https://righttothecitymtl.wordpress.com/2012/08/15/urban-spatialjustice/

14- Raveshty, M., Hoseyni, A., The Assessment of Distribution and State of Citizens Access to Cultural and Recreational Utilities from Spatial Justice Perspective: A Case Study Tehran 117th Urban Regions. Asia Geospatial Forum, 1(1).

15- Schwab, E. (2018). Spatial Justice and Informal Settlements: Integral Urban Projects in the Comunas of Medellin. United Kingdom: Emerald Publishing.

16- Shawkat, Y., \& Khalil, A. (2016, june). The Built Environment Budget FY 2015/2016: An Analysis of Spatial Justice in Egypt. Retrieved 2018, from Marsadomran: Marsadomran.info 
17- Simpson, M. D. (2013). Urbanising Favelas, Overlooking People: Regressive Housing Policies in Rio de Janeiro's Progressive Slum Upgrading Initaiatives . University College London.

18- Soja, E. W. (2010). Seeking Spatial Justice. London: University of Minnesota Press.

19- Tadamun. (2013). The Right to Information in the Egyptian Constitution [online]. Retrieved 2018, from http://www.tadamun.co/the-right-toinformation/?lang=en\#.XJeRvy2B3OQ

20- Tadamun. (2015, December 15). Spatial Justice in Greater Cairo [online]. Retrieved 2018, from http://www.tadamun.co/2015/12/15/investigating-spatial-inequalitycairo/?lang=en\#.W73v_i17HdQ

21- TU Berlin. (2010). Improving Informal Areas in Greater Cairo; The Case of Ezzbet Al Nasr and Dayer El Nahia. Egypt: GTZ.

22- www.worldbank.org 